\title{
Ikasleen ahotsak: guztiontzako eskola eraikitzeko gakoa
}

\author{
Students'voice: the key to build a school for all
}

\author{
Irati Sagardia Iturria, Agurtzane Martínez Gorrochategui* \\ Humanitate eta Hezkuntza Zientzien Fakultatea \\ Mondragon Unibertsitatea
}

LABURPENA: Ikastetxe guztietan dagoen aniztasunaren aurrean, indarra hartu du kalitatezko eta ekitatezko hezkuntza inklusiboaren ikuspegiak. Artikulu honetan, ikerketa proiektu baten prozesu eta emaitzak aurkezten dira eta proiektu honetan orain arte sisteman isilduak izan diren protagonisten ahotsak jaso dira. Proiektuan parte hartu dute Gipuzkoan kokatzen den eskola bateko Lehen Hezkuntzako ikasle guztiek eta helburua izan da ezagutzea ikasleek eskolan dituzten sentimendu eta bizipenak. Horretarako, galdetegiak, ikasleen ahotsa azaleratzen laguntzen duten teknikak eta eztabaida-taldeak erabili dira. Emaitzek adierazi dute ikasleek zeresan handia daukatela eskolako kulturan, politikan eta praktiketan eta, alderdi positiboak azaleratu dituzten arren, oztopoak ere bizi dituztela eskolako partehartzeari eta ikaste-prozesuei dagokienez. Beraz, ikerketan honetan ikasleak entzuteko beharra baieztatzen da, eskolako bizikidetza, parte-hartzea eta ikaste-prozesuak errazteko neurriak eta estrategiak diseinatzeko.

GAKO-HITZAK: lehen hezkuntza, ikasleen ahotsa, parte-hartzea, ikaste-prozesuak, hezkuntza inklusiboa

ABSTRACT: Inclusive education, a philosophy which advocates ensuring quality and equity for all children has become a driving force in the education movement due to diversity inside school rooms. This article presents the process and results of a research project that endeavours to contribute to the promotion of inclusive educational processes by collecting the voices of protagonists, until now silenced in the system. The aim was to involve the participation of all the students of a primary school in Gipuzkoa to know the feelings and experiences they have in school from an inclusive perspective. For those purpose questionnaires, special techniques for giving a voice to students and focus groups have been used as data collection tools. The results of the study indicate that the students as a whole, contribute interesting ideas related to the culture, practice and politics of the school and identify obstacles concerning participation and learning processes. This study confirms the need to listen to the voices of the protagonists to design measures and strategies that facilitate school life, participation and learning processes.

KEYWORDS: primary education, students' voice, participation, learning-processes, inclusive education

\footnotetext{
* Harremanetan jartzeko / Corresponding author: Agurtzane Martínez Gorrochategui. Mondragon Unibertsitatea. Humanitate eta Hezkuntza Zientzien Fakultatea. Dorleta auzoa z/g. 20540 - Eskoriatza. Gipuzkoa - amartinez@mondragon.edu- http://orcid.org/0000-0003-3927-3025
}

Nola aipatu / How to cite: Sagardia Iturria, Irati; Martínez Gorrochategui, Agurtzane. (2019). «lkasleen ahotsak: guztiontzako eskola eraikitzeko gakoa»; Tantak, 31(1), 121-147. (https://doi.org/10.1387/tantak.20479).

Jasotze-data: 2018/12/22 Onartze-data: 2019/04/08.

ISSN 0214-9753 - elSSN 2444-3581 / (c) 2019 UPV/EHU

(c) (i) Obra hau Creative Commons Atribución 4.0 Internacional-en

lizentziapean dago 
Irati Sagardia Iturria, Agurtzane Martínez Gorrochategui

\section{SARRERA}

Azken hamarkada hauetan, hezkuntza inklusiboa bultzatu egin behar dela adierazi da nazioarteko hainbat deklarazio, foro eta egitasmotan (La Educación Inclusiva: el camino hacia el futuro 2008, Informe de seguimiento de la Educación para todos en el Mundo 2015, HEZIBERRI 2020, Marco de Acción Educación 2030). Haur guztiak eskolaratu behar direla azpimarratu da, batez ere, babesgabe edo baztertuak dauden horiek, betiere kalitatezko eta ekitatezko hezkuntza eskainiz (Eusko Jaurlaritza, 2012; UNESCO, 2016). Hezkuntza inklusiboak aniztasuna barne hartzen du, eta aniztasunari erantzun egokia emateko, beharrezkoa da eskolan klima emozional bat sortzea, bertan dauden kideak bertako senti daitezen eta komunitate bat osa dezaten, horrela, bada, ikasle guztiek ikasi eta parte hartuko baitute (Blanco, 2008; Echeita eta Sandoval, 2002; Echeita, 2008). Prozesu horiek gauzatzeko eta eskolan giro hori lortzeko, ordea, hezkuntza-komunitate osoa kontutan hartu beharra dago (Lopez, 2007).

Filosofia eta sinesmen sendoek ezaugarritzen dute eskola inklusiboa. Batez ere, aniztasunaren errespetuarekiko balioek, kolaborazioak, parte-hartzeak, ekitateak eta solidaritateak (Dyson eta Millward, 2000; Ainscow et al., 2006). Ezaugarri komun horien bitartez, indibiduo bakoitzaren ikaste-prozesua erdigunetzat hartzen da eskolako erabaki eta praktiketan (Corbett, 2001). Eskolek ahalbidetu behar dute guztien ongietorria, eta komunitateak sortuz denen parte-hartzea bultzatu behar dute (Arnaiz, 2003; Booth et al., 2000). Hala eta guztiz ere, Susinos-ek eta Ceballos-ek (2012) dioten bezala, ikerketa gutxi daude hobekuntzari begira ikasleak ikerketaren erdian jartzen dituztenak, haien ahotsak, haien eskaerak. Ohikoagoak dira irakasleen praktika profesionala indartzera bideratuta dauden ikerketak. Horregatik, beharrezkotzat jotzen da, hezkuntza inklusiboa bermatze aldera, estrategia moduan zentroko behar eta oztopoak identifikatzea (Alvarez, Grau eta Tortosa, 2014) ikasleen ahotsaz baliatuz.

Cheminais-ek (2008) dioen bezala, Xx. mendean dauka jatorria ikasleen ahotsaren mugimenduak; garai hartan, ikasleak pasibo, isil, obediente, otzan eta ezgai moduan hartzen ziren; ikusten ziren, baina ez ziren entzuten. Ikuspegi hori, ordea, aldatu egin zen Haurren Eskubideei buruzko Hitzarmenean (1989). Bertan, haur orok berari dagozkion gaietan bere iritzia libreki adierazteko eskubidea duela zehaztu zen. Horrela, haurrak entzun egin behar direla aldarrikatzeaz gain, haiei dagozkien gaien inguruan entzuteko eta erabakiak hartzeko eskubidea dutela ere azpimarratzen da, ikasle guztiek baitauzkate nahiak, iritziak, zer esanak... (Susinos eta Ceballos, 2012). Izan ere, haurrak entzunak izateko eskubideaz gain, haien ahotsa berek ere hobeto ulertzeko baliabide garrantzitsua da; eta horrela bakarrik izango gara gai beren inguruan gehiago ezagutzeko eta laguntzeko (Messiou, 2012; Tertoolen et al., 2016). 
Ikasleak «ahots ezkutu» moduan ikus daitezke, baina, entzuten badira, lagungarriak dira ikasgela eta eskola inklusiboen garapenean (Ainscow, Booth eta Dyson, 1999). Haurrak entzuteak hainbat onura ekartzen ditu; izan ere, ikasleen ahotsek bidera gaitzakete helduentzako ikusezinak diren norabideetara (Mahbub, 2016). Ikasleen perspektibak ezagutzeak asko laguntzen du praktiken inguruan hausnartzen eta hobekuntzarako ildoak identifikatzen. Gauzak horrela, Messiouk (2012) bere lanean bildu bezala, ikasleen ahotsak lagunduko du ezagutza sakonagoa izaten eskaintzen zaizkien esperientzien inguruan.

Kontuan hartuta Espainiako Hezkuntza Sistema gelditua dagoela eta inklusioaren eremuak atzerapauso bat eman duela (Alvarez, Grau, eta Tortosa, 2014; UNESCO, 2010), gure helburua da ikasleen ahotsak jasotzeko teknika egokiak esploratzea, eta, horien bidez, eskola batean Lehen Hezkuntzako ikasle guztiek ikaste-prozesuen eta partaidetzaren inguruan dituzten bizipen eta esperientziak ezagutzea. Izan ere, ikasleek beste perspektiba bat eskaintzen dute inklusiora bidean (Mahbub, 2016). Inklusioaren arloan hobekuntzak egin daitezen, beharrezkoa da ikasleei beren esperientziagatik galdetzea, inklusioa ikasleen ongizatearekin baitago lotua (Messiou, 2003; Mahbub, 2008). Beraz, ikerketa honetan ikasleen ahotsen bitartez eskolan ikasteko eta parte hartzeko oztopoak identifikatu nahi ditugu umeen hobekuntza proposamenak jasoz.

Helburu horiek gauzatzeko asmoz, galdera batzuk planteatu dira.

1. Zer adierazten dute Lehen Hezkuntzako ikasleek, beren eskolatik zer gustatzen zaien eta zer ez galdetzean?

2. Hezkuntza inklusiboari begira, zein dira alderdi esanguratsuenak?

3. Zikloen artean bada ezberdintasunik?

4. Zein dimentsiotan daude hobetzeko proposamen gehien?

5. Zer-nolako hobekuntzak proposatzen dituzte ikasleek?

\section{PARTE-HARTZAILEAK}

Ikerketa honetan, Gipuzkoako eskola txiki bateko Lehen Hezkuntzako ikasle guztiek parte hartu dute, 39 ikaslek guztira. Ikasgelak zikloka nahastuta daudenez, hiru ikasgelatan eraman da aurrera ikerketa.

1. taula

Laginaren deskribapena

\begin{tabular}{lcccccc}
\hline & \multicolumn{2}{c}{ 1. ZIKLOA } & \multicolumn{2}{c}{ 2. ZIKLOA } & \multicolumn{2}{c}{ 3. ZIKLOA } \\
\hline & 1. MAILA & 2. MAILA & 3. MAILA & 4. MAILA & 5. MAILA & 6. MAILA \\
\cline { 2 - 7 } NESKA & 3 & 2 & 2 & 5 & 3 & 0 \\
MUTIL & 3 & 7 & 3 & 4 & 5 & 2 \\
\hline
\end{tabular}


Ikerketa hau hasi baino lehen, eskolarekin harremanetan jarri ginen, ikerketaren nondik norakoak azaldu genizkien, eta baimena eskatu genien ikerketa bertan gauzatzeko. Erantzuna baiezkoa izanik, ikerketa haurrekin gauzatu dela kontuan hartuta, bai gurasoei eta baita umeei ere dokumentu bat eman zitzaien ikerketaren nondik norakoak azalduz eta baimena eskatuz. Gauzak horrela, gurasoen baimena jaso ondoren, haurrei ere dokumentu bat sinatzeko eskatu zaie, horrela, baimena ematen dutela ziurtatuz. Uneoro, parte-hartzaile guztiek argi izan dute zein den ikerketaren helburua, beren funtzioa, eta norberak aukeratu du parte hartu ala ez. Hasieratik garbi utzi zaie, prozesuan zehar momenturen batean jarraitu nahi ez badute, askatasuna eta eskubidea daukatela ez jarraitzeko. Izan ere, momentu oro, gure ardura izan da haiek gustura egotea.

\section{METODOLOGIA}

Ikerketa honen helburuei erantzuteko, metodologia mistoa aukeratu da. Chen-ek (2006) honela definitzen du: ikerketa batean argazki osoa lortzeko helburuarekin ematen den metodo kualitatibo eta kuantitatiboen integrazio sistematikoa. Horiek nahi moduan konbina daitezke hurbilketa kualitatibo eta kuantitatiboek beren jatorrizko estruktura eta prozedurak mantentzeko; baina baita metodo horiek egokituak, aldatuak edo sintetizatuak izan daitezen ere (Hernandez, Fernandez eta Baptista, 2014: 534).

Kasu honetan, galdetegiak, talde-elkarrizketak eta eztabaida taldeak erabili dira; hau da, metodo kuantitatibo eta kualitatiboak. Talde-elkarrizketen bidez lortu diren datuak jasotzeko, teknika bereziak erabili dira, elkarrizketak eta eztabaidak biziagoak eta dibertigarriagoak izan daitezen ikasleentzat.

Teknika kuantitatiboaren bitartez eman zaio hasiera ikerketari. Horretarako, Index for Inclusion gidan oinarritzen den galdetegi bat erabili da. Mahbubek (2016) egokitu zuena bere ikerketa gauzatzeko. Horren bitartez, ikasleek duten perspektiba globala ezagutu nahi izan da, eta ondoren datu kualitatiboekin alderatu. Galderak hiru dimentsiotan banatu dira: kultura (1-18 galderak), politika (19-37) eta praktikak (38-50). Hala ere, dimentsio horiei dagozkien galderak ikasleentzat ulergarriak izateko moduan planteatu dira. Horretarako, 50 baieztapen eman zaizkie, «bai», «ez» eta «ez dakit» aukerekin. Ikasleentzat dinamikoagoa izateko helburuarekin, erantzuna adierazteko aurpegi-ikonoak eta galdera-ikurrak jarri zaizkie, 1. irudian ikus daitekeen bezala. Hartara, «bai» adierazteko irribarrez dagoen aurpegia; «ez» adierazteko, triste dagoena; eta «ez dakit» adierazteko galdera-ikurra borobildu behar izan dute. 


\section{Esaldiarekin ados zaude?}

\begin{tabular}{|l|l|l|l|c|}
\hline & & BAI & EZ & $\begin{array}{l}\text { EZ } \\
\text { DAKIT }\end{array}$ \\
\hline 1 & $\begin{array}{l}\text { Ikastetxean } \\
\text { pozik nago. }\end{array}$ & $\odot$ & $\bigodot$ & $?$ \\
\hline 2 & $\begin{array}{l}\text { Ikastetxera } \\
\text { etortzea gogoko } \\
\text { dut. }\end{array}$ & $\odot$ & $\odot$ & $?$ \\
\hline 3 & $\begin{array}{l}\text { Laguntza behar } \\
\text { dudanean } \\
\text { klasekoek } \\
\text { laguntzen } \\
\text { didate. }\end{array}$ & $\odot$ & $\odot$ & $?$ \\
\hline
\end{tabular}

1. irudia

Galdetegiaren adibidea

Bestetik, haurrak, gizabanako eta giza talde moduan, indargabe edo zaurgarritzat hartzen dira helduen ikuspegitik begiratuta (McDowell, 2001). Ikerlari helduek, beren presentziarekin eta bizi-esperientziekin, botere handiagoa adierazten dute haur parte-hartzaileen aurrean (Valentine, 1999). Metodo kualitatiboak, horren aurrean, gako hori hobeto kudeatzen laguntzen du. Izan ere, eskaintzen duen malgutasunaren bidez, aukera ematen du irekia izaten eta ez inposatzailea (Mahbub, 2016). Hau da, aukera ematen du botere-indarra gutxitzeko eta, horren ordez, parte-hartzaileen arteko kolaborazioa bermatzen du (Creswell, 2007). Ikerketa honetan, hainbat teknika berezi eta eztabaida-talde erabili dira ikasleen ahotsaz baliatzeko. Jarraian deskribatzen diren teknika hauen bitartez, ezagutu nahi izan dira ikasleek beren eskolan gustuko dituzten eta gustuko ez dituzten alderdiak, baita zer hobetuko luketen ere.

Talde-elkarrizketak. Eskolako hobekuntza-prozesuei begira tresna baliagarriak dira (Latess, 2008), eta beste teknikek eskaintzen ez dituzten abantailak errazten dituzte. Hala nola, giro eroso eta segurua sortzen laguntzen dute gai baten inguruan lasai hitz egiteko, eta norberaren iritziak azaleratzeko. Horretarako, aukera egokia ikusi da talde handian egitea, ondoren banaka alderdi ezberdinak adierazi dituzten arren, elkarren arteko babesa izan baitute; eta, horrela, ikertzaileak ez du saioa menderatu (Mayall, 2000).

- Sentimenduen dadoa. Izenak dioen bezala, sentimenduak azaleratzea du helburu nagusia teknika honek. Lehenengo aldiz, McNamarak eta Moretonek (1995) proposatu zuten emozioak aztertzeko. Geroago, besteak beste, ikasleek beren eskolan dauzkaten esperientziak azaleratzeko erabili da (Lindley, Brinkhuis eta Verhaar, 2011). Ikerketa honetan, eskolan bizi dituzten sentimendu ezberdinak eza- 
gutzeko erabili da, horrela, sentimendu ezberdinen bitartez, gustuko dituzten eta gustuko ez dituzten alderdiak identifikatu dituzte. Hau da, teknika honetan, ikasleei dado bat eman zaie talde handian. Dado horrek, zenbakiak izan ordez, aurpegi ezberdin bat izan du alde bakoitzean, eta aurpegi hori sentimendu batekin identifikatu da, 2. irudian ikus daitekeen bezala. Ikasle bakoitzak, dadoa botatzean egokitu zaion aurpegiaren arabera, sentimendu horri bideratutako esaldi bat osatu behar izan du: «Eskolan pozik/triste/urduri jartzen naiz...». Messiouk (2012) dioenaren arabera, Lehen Hezkuntzako ikasleak prozesuan lotzeko teknika bikaina da.

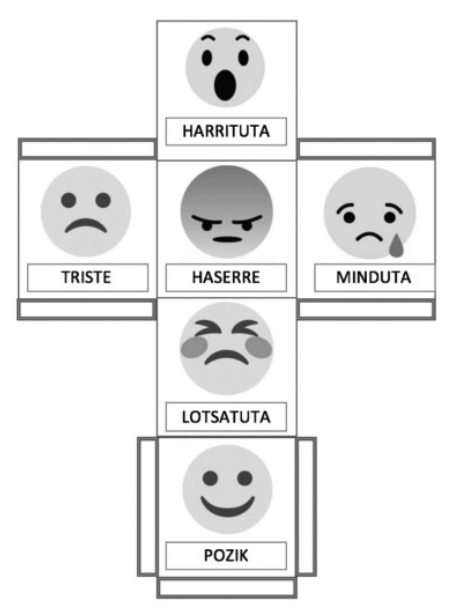

2. irudia

Sentimenduen dadoa

- Botilako mezua. Teknika hau Daviesek (2000) erabili zuen, Lehen Hezkuntzan dauden prozesu demokratikoak ulertzeko helburuarekin. Messiouk (2003), marjinazioa eskoletan zein haurrek jasan zezaketen anonimoki aztertzeko helburuarekin ere erabili zuen. Ikasleei beren ikastetxean gustatzen ez zitzaiena aztertzeko eta zer-nolako hobekuntzak proposatzen zituzten ezagutzeko erabili zen. Ikerketa honetan, haur bakoitzari bi esaldi luzatu zaizkie, eta esaldi bakoitzaren azpian hiru erantzun jartzeko lekua utzi zaie, 3. irudian ikus daitekeen bezala. Horrela, hiru erantzunak idatzi ostean, ikasle bakoitzak bere orria modu anonimoan botila batean sartu du. Aukera bikaina da arrotzagoak diren alderdiak azaleratzeko. Izan ere, Messiouk (2012) dioen bezala, haur eta gazteei aukera eskaintzen zaie adierazi nahi dutena beldurrik gabe adierazteko, modu anonimoan egiten baita. 
Ikasleen ahotsak: guztiontzako eskola eraikitzeko gakoa

\begin{tabular}{|l|l|}
\hline $\begin{array}{l}\text { Eskolan nagoenean ez zait } \\
\text { gustatzen... }\end{array}$ & Nire ikastetxean hobetuko nuke... \\
\hline 1. & 1. \\
\hline 2. & 2. \\
\hline 3. & 3. \\
\hline
\end{tabular}

3. irudia

Botilako mezua

- Circle time. Tresna erabilgarria da parte-hartzaileek beren eta besteen inguruan daukaten ezagutzaz hausnartzeko. Hainbat helburu lortzeko teknika da; esaterako, ikasleen gaitasun pertsonalak hobetzeko, gaitasun sozialak lantzeko, eta ikasle guztiei ahots berdina eskaintzeko (Collins, 2011); gaitasun sozialak eta jarrerak hobetzeko (Canney eta Byrne, 2006; Lown, 2002); baita entzuteko eta hitz egiteko gaitasuna hobetuz elkarren arteko kooperazioa bilatzeko ere (Housego eta Burns, 1994). Jarduerak iraun artean, ikasleak borobilean eseri dira, eta txandaka esaldia amaitu behar izan dute. Messiouk (2012) aipatu bezala, ikasleek beren ikastetxean gustuko dutena eta gustuko ez dutena identifikatzeko erabil daiteke, eta ikerketa honetan hori izan da teknika honen helburua. 4. irudian ageri dira erabilitako esaldiak.

- ESKOLAN GUSTUKO DUT...

- KLASEAN GUSTUKO DUT...

- ESKOLAN GEHIEN GUSTATZEN ZAIDANA...

- ESKolan GUtXIEN GUSTATZEN ZAIDANA...

- gelan gutxien gustatzen zaidanA...

- taldeAn lan egitea gustatzen zait...

- NAHIAGO DUT (BAKARRIK/TALDEAN) LAN EGIN..

- ONA NAIZ...

- gelan lanean ARI garenean gustatzen zait...

- EZ DA BIDEZKOA...

- ESKOLAN EZ NUKE ALDATUKO...

- ESKOLAN ALDATUKO NUKE...

- IRAKASLEA IZANGO BANINTZ...

4. irudia

Circle time 
- Diamantearen dinamika. Teknika hau ikasleen ahotsaren bitartez aniztasunari erantzuteko estrategia moduan erabili da, irakasleen garapen profesionalari begira, hiru urteko proiektu batean. Kasu honetan, ordea, ikasleen ikaste-prozesuetan garrantzitsuak diren alderdiak identifikatzeko teknika edo jarduera moduan erabili da. Teknika honetan, ikasleak lauzpabost pertsonako taldeetan jarri dira eta talde bakoitzari ikaste-prozesuekin erlazionatutako 15 esaldi banatu zaizkio; 15 esaldi horiek ezberdinak izan dira lehenengo zikloan eta gainontzeko bi zikloetan, ikasleen ulermen-mailara egokitu nahi izan baita. Lehendabizi, 15 esaldi horietatik 9 aukeratu behar izan dituzte, eta, ondoren, diamante baten forma emanez, 9 horietatik garrantzitsua dena goian jarri dute eta behean, aldiz, 9 horietatik beren ustez garrantzi gutxiena duena, eta gainontzekoak garrantzi-maila horren arabera. Amaitzeko, talde bakoitzak bere diamantea azaldu behar izan du talde handian zergatia justifikatuz.

\begin{tabular}{|c|c|c|}
\hline $\begin{array}{c}\text { GEHIAGO IKASTEN DA } \\
\text { GAUZAK ULERTUZ, } \\
\text { BURUZ IKASIZ BAINO }\end{array}$ & $\begin{array}{c}\text { IKASTEAK DIBERTIGARRIA } \\
\text { IZAN BEHAR DU }\end{array}$ & $\begin{array}{c}\text { GAUZAK EGINEZ, } \\
\text { GEHIAGO IKASTEN DA }\end{array}$ \\
\hline $\begin{array}{c}\text { ENTZUNEZ ETA IDATZIZ } \\
\text { ERRAZAGO IKASTEN DA }\end{array}$ & $\begin{array}{c}\text { IRAKURRIZ ERRAZAGO } \\
\text { IKASTEN DA }\end{array}$ & $\begin{array}{c}\text { IKASTEKO SERIO ETA } \\
\text { ISILIK EGON BEHAR DA }\end{array}$ \\
\hline $\begin{array}{c}\text { IKASTEAK BALIO DU } \\
\text { NOTA ONAK } \\
\text { ATERATZEKO }\end{array}$ & $\begin{array}{c}\text { IKASLEEK AUKERATU } \\
\text { BEHARKO LUKETE ZER } \\
\text { IKASI }\end{array}$ & $\begin{array}{c}\text { IRAKASLEEK AUKERATU } \\
\text { BEHARKO LUKETE } \\
\text { IKASLEEK IKASI BEHAR } \\
\text { DUTENA }\end{array}$ \\
$\begin{array}{c}\text { IKASTEAK BAKOITZAK } \\
\text { BERE BURUA ETA } \\
\text { BESTEENA EZAGUTZEKO } \\
\text { BALIO DU }\end{array}$ & $\begin{array}{c}\text { GAUZA GEHIAGO } \\
\text { JAKITEKO }\end{array}$ & $\begin{array}{c}\text { BAKARKA HOBETO } \\
\text { IKASTEN DA }\end{array}$ \\
\hline $\begin{array}{c}\text { TALDEAN LAN EGINDA } \\
\text { GEHIAGO IKASTEN DA }\end{array}$ & $\begin{array}{c}\text { IRAKASLEAK AZALDUTA } \\
\text { GEHIAGO IKASTEN DA }\end{array}$ & $\begin{array}{c}\text { GAUZAK GURE KABUZ } \\
\text { ULERTUTA GEHIAGO } \\
\text { IKASTEN DA }\end{array}$ \\
\hline
\end{tabular}

5. irudia

Diamantearen teknika (bigarren eta hirugarren zikloak) 
Eztabaida-taldeak. Teknika hau hainbat ikerketatan erabili da, ikasleek esan nahi dutena sakontasun handiagoz ezagutzeko eta ikasleen parte-hartze aktiboa ikerketan bermatzeko (Mahbub, 2016; Messiou, 2003). Ikerketa honetan ere, aurreko teknika guztietan sakontzeko helburuarekin, pentsatu da aukera egokia dela talde-elkarrizketekin amaitzea, 6. irudian ageri diren galderen bitartez. Izan ere, talde-eztabaidak pertsona gutxiz osaturiko taldeak dira, non, moderatzaile baten bitartez, gai ezberdinen inguruan bakoitzak dituen ikuspegiak eta ideiak partekatzen baitira:

1. Zer da zuen eskolan gehien gustatzen zaizuena?

2. Zer da zuen eskolan gutxien gustatzen zaizuena?

3. Nolakoa da ikasleen arteko harremana?

4. Eta irakasleekin daukazuen harremana?

5. Eskolan zein arazo identifikatzen dituzue?

6. Gaiak lantzerakoan zein motatako arazoak izaten dituzue?

7. Eskolan zer hobetuko zenukete?

6. irudia

Eztabaida-taldeko galderak

\section{INFORMAZIOAREN ANALISIAREN PROZEDURA}

Teknika ezberdinen bitartez datuak jaso ostean, horien azterketa egin da. Lehenik eta behin, datu kuantitatiboak aztertu dira. Ikasleek beren ikastetxeari buruz adierazten dutena modu globalean ezagutzeko helburuarekin aztertu dira galdetegiak. Horrela, item bakoitzaren bitartez, ezagutu dira ikasle kopurua, nesken eta mutilen arteko ezberdintasunak, eta mailen artean ezberdintasunik dagoen.

Aipatu bezala, item bakoitzaren inguruan «bai», «ez» edo «ez dakit» adierazi dute ikasleek. Emaitzak aztertzeko SPSS programa erabili da, eta, aldagai guztiak nominalak direla kontuan hartuta, aukera eman du maiztasun-taulen bitartez erantzunen maiztasuna eta portzentajea jakiteko. Baina, horrez gain, kontingentzia-taulen bitartez, sexuaren arabera eta baita mailaka eta zikloka ere, erantzunak alderatzeko aukera eskaini du programak.

Teknika kualitatiboei dagokienez, talde-elkarrizketa eta eztabaida-taldeen bitartez jasotako datuak kategoria ezberdinetan banatu dira. Kategoria horiek Index for Inclusion gidako hiru dimentsioei dagozkie: kulturari, politikari eta praktikari. Kasu honetan, oinarri moduan hartu dira, ikasleek esandakoa inklusioaren perspektibatik aztertzeko. Izan ere, Boothek eta Ainscowek (2002) dioten bezala, tresna baliagarria da eskolako hobekuntzak 
bideratzeko. Horregatik, ikasleek beren eskolaz adierazten dutena ikuspegi inklusibo batetik bideratzeko helburuarekin erabili dira hiru dimentsioak kategoria moduan hartuta. Horrela, jasotako datuak taula ezberdinetan antolatu dira, modu horretan errazagoa izan baita informazioa aztertzea.

\section{EMAITZAK}

Jarraian, dimentsioka lortutako emaitzak laburbilduko dira. Dimentsio bakoitzaren hasieran galdetegien bitartez lortutako emaitzak taula batean aurkeztu dira. Bertan, 38 ikasleren emaitzak ehunekotan ageri dira eta, ondoren, taularen azpian, gainontzeko teknika kualitatiboen bitartez jasotako datuak aurkezten dira.

\section{Kultura}

2. taula

Galdetegiko kulturaren emaitzak

\begin{tabular}{|c|c|c|c|c|c|}
\hline ITEMAK & & GUZTIRA & 1. ZIKLOA & 2. ZIKLOA & 3. ZIKLOA \\
\hline \multirow{3}{*}{$\begin{array}{l}\text { 1. Ikastetxean pozik } \\
\text { nago. }\end{array}$} & BAI & $\% \mathbf{8 6 , 8}$ & $\% 29$ & $\% 31,6$ & $\% 26,4$ \\
\hline & EZ & $\% 0$ & $\% 0$ & $\% 0$ & $\% 0$ \\
\hline & $\begin{array}{l}\text { EZ } \\
\text { DAKIT }\end{array}$ & $\% 13,2$ & $\% 7,9$ & $\% 5,2$ & $\% 0$ \\
\hline \multirow{3}{*}{$\begin{array}{l}\text { 2. Ikastetxera etortzea } \\
\text { gogoko dut. }\end{array}$} & BAI & $\% 79,8$ & $\% 34,3$ & $\% 36,9$ & $\% 7,9$ \\
\hline & EZ & $\% 10,5$ & $\% 0$ & $\% 0$ & $\% 10,5$ \\
\hline & $\begin{array}{l}\text { EZ } \\
\text { DAKIT }\end{array}$ & $\% 10,5$ & $\% 2,6$ & $\% 0$ & $\% 7,9$ \\
\hline \multirow{3}{*}{$\begin{array}{l}\text { 3. Laguntza behar } \\
\text { dudanean klasekoek } \\
\text { laguntzen didate. }\end{array}$} & BAI & $\%$ 73,7 & $\% 13,2$ & $\% 34,2$ & $\% 26,4$ \\
\hline & $\mathrm{EZ}$ & $\% 13,2$ & $\% 10,5$ & $\% 2,6$ & $\% 0$ \\
\hline & $\begin{array}{l}\text { EZ } \\
\text { DAKIT }\end{array}$ & $\% 13,2$ & $\% 13,1$ & $\% 0$ & $\% 0$ \\
\hline \multirow{3}{*}{$\begin{array}{l}\text { 4. Laguntza behar } \\
\text { dutenean klasekoei } \\
\text { laguntzen diet. }\end{array}$} & BAI & $\% 94,7$ & $\% 34,2$ & $\% 34,2$ & $\% 26,4$ \\
\hline & $\mathrm{EZ}$ & $\% 2,6$ & $\% 2,6$ & $\% 0$ & $\% 0$ \\
\hline & $\begin{array}{l}\text { EZ } \\
\text { DAKIT }\end{array}$ & $\% 2,6$ & $\% 0$ & $\% 2,6$ & $\% 0$ \\
\hline \multirow{3}{*}{$\begin{array}{l}\text { 5. Lagun onak ditut } \\
\text { ikastetxean. }\end{array}$} & BAI & $\% 97,4$ & $\% 34,2$ & $\% 36,9$ & $\% 26,4$ \\
\hline & $\mathrm{EZ}$ & $\% 0$ & $\% 0$ & $\% 0$ & $\% 0$ \\
\hline & $\begin{array}{l}\text { EZ } \\
\text { DAKIT }\end{array}$ & $\% 2,6$ & $\% 2,6$ & $\% 0$ & $\% 0$ \\
\hline
\end{tabular}


Ikasleen ahotsak: guztiontzako eskola eraikitzeko gakoa

\begin{tabular}{|c|c|c|c|c|c|}
\hline ITEMAK & & GUZTIRA & 1. ZIKLOA & 2. ZIKLOA & 3. ZIKLOA \\
\hline \multirow{3}{*}{$\begin{array}{l}\text { 6. Guztiok } \\
\text { errespetatzen dugu } \\
\text { elkar. }\end{array}$} & BAI & $\% 63,2$ & $\% 34,3$ & $\% 2,6$ & $\% 26,4$ \\
\hline & EZ & $\% 2,6$ & $\% 2,6$ & $\% 0$ & $\% 0$ \\
\hline & $\begin{array}{l}\text { EZ } \\
\text { DAKIT }\end{array}$ & $\% 34,2$ & $\% 0$ & $\% 34,2$ & $\% 0$ \\
\hline \multirow[t]{3}{*}{ 7. Iseka egiten didate. } & BAI & $\% 28,9$ & $\% 18,4$ & $\% 10,6$ & $\% 0$ \\
\hline & EZ & $\% 50$ & $\% 18,5$ & $\% 7,9$ & $\% 23,7$ \\
\hline & $\begin{array}{l}\text { EZ } \\
\text { DAKIT }\end{array}$ & $\% 21,1$ & $\% 0$ & $\% 18,4$ & $\% 2,6$ \\
\hline \multirow{3}{*}{$\begin{array}{l}\text { 8. Besteei iseka egiten } \\
\text { diet. }\end{array}$} & BAI & $\% 10,5$ & $\% 5,2$ & $\% 5,3$ & $\% 0$ \\
\hline & EZ & $\% \mathbf{8 6 , 8}$ & $\% 31,6$ & $\% 31,6$ & $\% 23,7$ \\
\hline & $\begin{array}{l}\text { EZ } \\
\text { DAKIT }\end{array}$ & $\% 2,6$ & $\% 0$ & $\% 0$ & $\% 2,6$ \\
\hline \multirow{3}{*}{$\begin{array}{l}\text { 9. Ikastetxean } \\
\text { pertsona batzuk } \\
\text { baztertzen dira. }\end{array}$} & BAI & $\% 31,6$ & $\% 5,3$ & $\% 21,1$ & $\% 5,3$ \\
\hline & EZ & $\%$ 44,7 & $\% 31,6$ & $\% 2,6$ & $\% 10,5$ \\
\hline & $\begin{array}{l}\text { EZ } \\
\text { DAKIT }\end{array}$ & $\% 23,7$ & $\% 0$ & $\% 13,1$ & $\% 10,5$ \\
\hline \multirow{4}{*}{$\begin{array}{l}\text { 10. Arazoren bat } \\
\text { dudanean } \\
\text { irakasleari lasai } \\
\text { esan diezaioket eta } \\
\text { laguntzen dit. }\end{array}$} & BAI & $\% 97,4$ & $\% 36,9$ & $\% 44,2$ & $\% 26,4$ \\
\hline & $\mathrm{EZ}$ & $\% 2,6$ & $\% 0$ & $\% 2,6$ & $\% 0$ \\
\hline & $\mathrm{EZ}$ & & & & \\
\hline & DAKIT & $\% 0$ & $\% 0$ & $\% 0$ & $\% 0$ \\
\hline \multirow{3}{*}{$\begin{array}{l}\text { 11. Nesken eta mutilen } \\
\text { artean ondo } \\
\text { moldatzen gara. }\end{array}$} & BAI & $\%$ 94,7 & $\% 36,9$ & $\% 31,6$ & $\% 26,4$ \\
\hline & $\mathrm{EZ}$ & $\% 2,6$ & $\% 0$ & $\% 2,6$ & $\% 0$ \\
\hline & $\begin{array}{l}\text { EZ } \\
\text { DAKIT }\end{array}$ & $\% 2,6$ & $\% 0$ & $\% 2,6$ & $\% 0$ \\
\hline \multirow{3}{*}{$\begin{array}{l}\text { 12. Lanak egiteko } \\
\text { pertsona batzuk } \\
\text { beste batzuk baino } \\
\text { denbora gehiago } \\
\text { behar dutela } \\
\text { ulertzen dut. }\end{array}$} & BAI & $\% 94,7$ & $\% 34,3$ & $\% 34,2$ & $\% 26,4$ \\
\hline & $\mathrm{EZ}$ & $\% 5,3$ & $\% 2,6$ & $\% 2,6$ & $\% 0$ \\
\hline & $\begin{array}{l}\text { EZ } \\
\text { DAKIT }\end{array}$ & $\% 0$ & $\% 0$ & $\% 0$ & $\% 0$ \\
\hline \multirow{3}{*}{$\begin{array}{l}\text { 13. Irakaslea gustuko } \\
\text { dut. }\end{array}$} & BAI & $\% 97,4$ & $\% 36,9$ & $\% 34,9$ & $\% 26,4$ \\
\hline & $\mathrm{EZ}$ & $\% 0$ & $\% 0$ & $\% 0$ & $\% 0$ \\
\hline & $\begin{array}{l}\text { EZ } \\
\text { DAKIT }\end{array}$ & $\% 2,6$ & $\% 0$ & $\% 2,6$ & $\% 0$ \\
\hline
\end{tabular}


Irati Sagardia Iturria, Agurtzane Martínez Gorrochategui

\begin{tabular}{|c|c|c|c|c|c|}
\hline ITEMAK & & GUZTIRA & 1. ZIKLOA & 2. ZIKLOA & 3. ZIKLOA \\
\hline \multirow{3}{*}{$\begin{array}{l}\text { 14. Irakasleak gustuko } \\
\text { nau. }\end{array}$} & BAI & $\% 63,2$ & $\% 36,9$ & $\% 15,8$ & $\% 10,5$ \\
\hline & EZ & $\% 0$ & $\% 0$ & $\% 0$ & $\% 0$ \\
\hline & $\begin{array}{l}\text { EZ } \\
\text { DAKIT }\end{array}$ & $\% \mathbf{3 6 , 8}$ & $\% 0$ & $\% 21,1$ & $\% 15,8$ \\
\hline \multirow{3}{*}{$\begin{array}{l}\text { 15. Arazoak ditugunean } \\
\text { badakigu nola } \\
\text { konpondu behar } \\
\text { ditugun. }\end{array}$} & BAI & $\% 71,1$ & $\% 36,9$ & $\% 10,5$ & $\% 23,7$ \\
\hline & EZ & $\% 0$ & $\% 0$ & $\% 0$ & $\% 0$ \\
\hline & $\begin{array}{l}\text { EZ } \\
\text { DAKIT }\end{array}$ & $\%$ 28,9 & $\% 36,9$ & $\% 26,3$ & $\% 2,6$ \\
\hline \multirow{3}{*}{$\begin{array}{l}\text { 16. Irakasleak guk } \\
\text { egindako esfortzua } \\
\text { beti kontutan } \\
\text { hartzen du. }\end{array}$} & BAI & $\% 97,4$ & $\% 36,9$ & $\% 34,2$ & $\% 26,4$ \\
\hline & EZ & $\% 0$ & $\% 0$ & $\% 0$ & $\% 0$ \\
\hline & $\begin{array}{l}\text { EZ } \\
\text { DAKIT }\end{array}$ & $\% 2,6$ & $\% 0$ & $\% 2,6$ & $\% 0$ \\
\hline \multirow{3}{*}{$\begin{array}{l}\text { 17. Besteen esfortzua } \\
\text { baloratzen dut. }\end{array}$} & BAI & $\% 97,4$ & $\% 36,9$ & $\% 34,2$ & $\% 26,4$ \\
\hline & EZ & $\% 0$ & $\% 0$ & $\% 0$ & $\% 0$ \\
\hline & $\begin{array}{l}\text { EZ } \\
\text { DAKIT }\end{array}$ & $\% 2,6$ & $\% 0$ & $\% 2,6$ & $\% 0$ \\
\hline \multirow{3}{*}{$\begin{array}{l}\text { 18. Besteek nire } \\
\text { esfortzua baloratzen } \\
\text { dute. }\end{array}$} & BAI & $\% 57,9$ & $\% 21$ & $\% 26,3$ & $\% 10,5$ \\
\hline & EZ & $\% 0$ & $\% 0$ & $\% 0$ & $\% 0$ \\
\hline & $\begin{array}{l}\text { EZ } \\
\text { DAKIT }\end{array}$ & $\%$ 42,1 & $\% 15,8$ & $\% 10,6$ & $\% 15,8$ \\
\hline
\end{tabular}

Kultura aipatzean, komunitate seguru, abegikor, lankidetzazko eta estimulatzailea sortzearen inguruan hitz egiten da, modu horretan, norbanako bakoitza balioetsia izan dadin, hori baita ikasleek lorpen-maila handiagoa edukitzeko modua (Booth eta Ainscow, 2002). Beraz, Eusko Jaurlaritzak (2012) dioen bezala, kultura inklusiboak sortzeko bi alderdi izango dira funtsezkoak: komunitatea sortzea eta balio inklusiboen baitan aritzea.

Hori kontuan hartuta, atal honetan honako kategoria hauek nabarmendu dira ikasleen ahotsetik dimentsio horren inguruan:

- Komunitateko partaide sentitu. Kategoria honek erreferentzia egiten dio ikasleak eskolan daudenean gustura sentiarazten dituen horri, horrek pozik sentiarazten baititu. 2. taulan ikus daitekeen bezala, ikasleek orokorrean ikastetxera joatea gogoko dute $(\% 79,8)$ eta ikastetxean pozik daude $(\%$ 86,8). Adierazi dutenaren arabera, haientzat oso garrantzitsua da lagunekin egotea, ondo pasatzen baitute: «Lagunekin nagoenean pasatzen dut ondo klasean» eta 
$\%$ 97,4k adierazi duenaren arabera, lagun onak dituzte ikastetxean. Datuen emaitzek adierazten dute orokorrean ziklo berdineko ikasleen arteko harremana ona dela, eta hori, lanari dagokionez, garrantzitsua da berentzat. Alde batetik, elkarri laguntzen diotelako. Galdetegian ikusi bezala \% 73,7k adierazi du laguntza behar dutenean laguntza jasotzen dutela. Zikloen artean ezberdintasuna eman da izan ere, 3.zikloan guztiek horrela sentitzen duten arren, bigarren zikloan \% 10,5ek ezetz adierazi du (ikus 2. taula). Horrela, ikasleek adierazi dute garrantzitsua dela harreman ona izatea lana hobeto egiten dutelako, gogotsu:

«- Norbaitekin haserre bazaude lana ez duzu ondo egiten, baino harreman ona badaukazu egiten da hobeto.

- Lana gogoarekin.

- Bai, hori da».

- Komunitateko partaide ez sentitu. Alderantziz, ikasleei ez zaie gustatzen sentitzea komunitate (eskola) horretako partaide ez direla. Hori gertatzen denean, minduta, triste eta haserre sentitzen dira. Haiek azaleraturiko sentimendu eta esperientzia horietatik identifikatu da ikasleek ez dituztela zenbait arau ulertzen, ez baitie inongo zentzurik bilatzen: «Irakaslea izango banintz, ez nituzke jarriko norma arraro horiek daudenak orain». Baina, horrez gain, ez dute bidezko ikusten irakasleek beren iritziak kontuan hartu gabe erabakiak hartzea: «Ke, ez da juxtua al dala ekarri etxeko materiala bakarrik ostegunetan. Adibidez, larruzko baloia. Beraiek erabaki dutelako».

Dimentsio honetan, \% 31,6k adierazi du ikastetxean pertsona batzuk baztertu egiten direla eta horrekin lotuta, bazterkeria-egoerak ere identifikatu dira. Bertan, hainbat alderdi bereizi dira. Horrela, ikasleek sentimendu negatiboak adierazi dituzte, batzuetan, bakarrik sentitzen direla adieraztean: «Nago triste batzuetan bakarrik nagoenean, sentitzen naizenean» eta baztertuak sentitzen direnean: «Gelan gutxien gustatzen zaidana da baztertzen nautenean». Irainak eta isekak ere askotan azaleratu diren alderdiak dira. Horrenbestez, beren eskola-bizitzaz kontatu dutenaren arabera, honako egoera hauek ez zaizkie batere gustatu: «Txikitin deitzen didatenean da gelan gutxien gustatzen zaidana»; sentimendu negatiboak ere eragiten dizkie: «Haserre, ba burla egiten didatenean», «Triste, ba... burla egiten didatenean». «Gelan gutxiena gustatzen zaidana da zerbait gaizki egiten dudanean barre egiten didatenean». Hala ere, \% 10,5ek onartu du besteei iseka egiten diela eta \% 28,9k adierazi du besteek berari iseka egiten dietela. Horrekin lotuta, ezberdintasuna eman da zikloen artean. Izan ere, 3. zikloko ikasleek bi kasuetan ez dute baietzik adierazi (ikus 2. taula). 
Erasoen inguruan, esanguratsua izan da 16 esalditatik 10etan ikasle berberarengana zuzendu direla. Horrela, ikusi da ikasle zehatz batek askotan erasotzen dituela gelakideak: «Gelan gutxien gustatzen zaidana da ikasle_lek guri gauza txarrak egiten dizkigunean». Bestalde, haserretzen direnean, esandakoaren arabera, identifikatu da momentu batzuetan gehiago justifikatzen dutela erasoa besteetan baino: «Norbaitek besteari arrazoi gabe jotzea ez da juxtua».

Ikasleek ekitate falta adierazi dute patioaren erabilerari buruz. Arazo hori dela eta, bederatzi aldiz aipatu dute zaharrenak baliatzen direla patioaz; eta, horri lotuta, adierazi dutenaren arabera, erdipurdikoa da zikloen arteko harremana: «Nago hasarre handiek kanpoa beti kentzen digutenean». Bai bigarren eta bai hirugarren zikloko ikasleek adierazi dutenaren arabera, txikiagoek babes handiagoa dutela pentsatzen dute, eta berei batzuetan laguntza falta zaiela: «Irakasleak beti jartzen dia txikien parte. Gu beti, ba batzutan egiten degu zerbait nahigabe eta beti daude beraien alde jakin gabe zer pasa den eta ez... ez dakizu... ez dute galdetzen eta egon biekin, ez... juten dira direktamente beraiengana eta guk ere behar degu laguntza». Hala ere, galdetegian ikusi denaren arabera, \% 97,4k dio arazoren bat dutenean irakasleei lasai esan eta haiek lagundu egiten dituztela.

Horrekin lotuta, arazo moduan ikusten dute komunikazioaren gaia. Adierazi dutenaren arabera, irakasleek ikasle batzuei etiketak ezartzen dizkiete, modu horretan ikasle batzuk babestuz: «Porke gauza bat pasatzen da patioan eta gero ez diogu esaten irakasleari eta beraiek begiratzen dute besteena. Adibidez, dago ume bat beti egiten diotela burla bezala eta gero beti berak jotzen die besteei, nazkatua bezala dago, eta orduan, irakasleak bakarrik fijatzen dira bestearengan. Osea umea nazkatuta dagona ez, besteei botatzen die kulpa eta ez dira konturatzen berak ere gaizki egiten duela».

- Porrotaren aurrean bizipenak. Kulturarekin amaitzeko, ikusi da zenbait ikaslek lotsa pasatzen duela jendaurrean bakarrik hitz egitean: «lotsatuta, zerbait azaldu behar detenean nik bakarrik jendearen aurrean»; baita antzeztu edo bertsotan egin behar dutenean ere, eta hori porrotari edo gaizki egiteari dioten beldurrarekin identifikatu da. 
Ikasleen ahotsak: guztiontzako eskola eraikitzeko gakoa

\section{Politika}

3. taula

Galdetegiko politikaren emaitzak

\begin{tabular}{|c|c|c|c|c|c|}
\hline ITEMAK & & GUZTIRA & 1. ZIKLOA & 2. ZIKLOA & 3. ZIKLOA \\
\hline \multirow{3}{*}{$\begin{array}{l}\text { 19. Talde-lana lan } \\
\text { indibiduala } \\
\text { bezain } \\
\text { garrantzitsua da. }\end{array}$} & BAI & $\% 97,4$ & $\% 36,9$ & $\% 36,9$ & $\% 23,7$ \\
\hline & EZ & $\% 2,6$ & $\% 0$ & $\% 0$ & $\% 2,6$ \\
\hline & $\begin{array}{l}\text { EZ } \\
\text { DAKIT }\end{array}$ & $\% 0$ & $\% 0$ & $\% 0$ & $\% 0$ \\
\hline \multirow{3}{*}{$\begin{array}{l}\text { 20. Taldeak egiten } \\
\text { direnean beti } \\
\text { talde berberak } \\
\text { izaten dira. }\end{array}$} & BAI & $\% 10,5$ & $\% 2,6$ & $\% 5,3$ & $\% 2,6$ \\
\hline & EZ & $\% \mathbf{5 7 , 9}$ & $\% 34,3$ & $\%$ 7,9 & $\% 15,8$ \\
\hline & $\begin{array}{l}\text { EZ } \\
\text { DAKIT }\end{array}$ & $\% 31,6$ & $\% 0$ & $\% 23,7$ & $\% 7,9$ \\
\hline \multirow{3}{*}{$\begin{array}{l}\text { 21. Pertsona } \\
\text { ezberdinak } \\
\text { egotea ona da. }\end{array}$} & BAI & $\% 97,4$ & $\% 36,9$ & $\% 36,9$ & $\% 23,7$ \\
\hline & $\mathrm{EZ}$ & $\% 0$ & $\% 0$ & $\% 0$ & $\% 0$ \\
\hline & $\begin{array}{l}\text { EZ } \\
\text { DAKIT }\end{array}$ & $\% 2,6$ & $\% 0$ & $\% 0$ & $\% 2,6$ \\
\hline \multirow{3}{*}{$\begin{array}{l}\text { 22. Ikastetxean } \\
\text { gauza asko egiten } \\
\text { ditut. }\end{array}$} & BAI & $\% 100$ & $\% 36,9$ & $\% 36,9$ & $\% 26,4$ \\
\hline & $\mathrm{EZ}$ & $\% 0$ & $\% 0$ & $\% 0$ & $\% 0$ \\
\hline & $\begin{array}{l}\text { EZ } \\
\text { DAKIT }\end{array}$ & $\% 0$ & $\% 0$ & $\% 0$ & $\% 0$ \\
\hline \multirow{3}{*}{$\begin{array}{l}\text { 23. Gure ikasgelan } \\
\text { egindako lana } \\
\text { ikastetxe osoak } \\
\text { ikus dezake. }\end{array}$} & BAI & $\% 31,6$ & $\% 7,9$ & $\% 5,2$ & $\% 18,4$ \\
\hline & EZ & $\% 28,9$ & $\% 29$ & $\% 0$ & $\% 0$ \\
\hline & $\begin{array}{l}\text { EZ } \\
\text { DAKIT }\end{array}$ & $\%$ 39,5 & $\% 0$ & $\% 31,6$ & $\% 7,9$ \\
\hline \multirow{3}{*}{$\begin{array}{l}\text { 24. Nota altuak eta } \\
\text { nota baxuak } \\
\text { ateratzen dituzten } \\
\text { pertsonak berdin } \\
\text { tratatzen dira. }\end{array}$} & BAI & $\% 100$ & $\% 36,9$ & $\% 36,9$ & $\% 26,4$ \\
\hline & EZ & $\% 0$ & $\% 0$ & $\% 0$ & $\% 0$ \\
\hline & $\begin{array}{l}\text { EZ } \\
\text { DAKIT }\end{array}$ & $\% 0$ & $\% 0$ & $\% 0$ & $\% 0$ \\
\hline \multirow{3}{*}{$\begin{array}{l}\text { 25. Ikastetxean nik } \\
\text { egindako lana } \\
\text { baloratzen da. }\end{array}$} & BAI & $\% \mathbf{7 6 , 3}$ & $\% 23,7$ & $\% 31,6$ & $\% 21,1$ \\
\hline & $\mathrm{EZ}$ & $\% 15,8$ & $\% 13,2$ & $\% 2,6$ & $\% 0$ \\
\hline & $\begin{array}{l}\text { EZ } \\
\text { DAKIT }\end{array}$ & $\% 7,9$ & $\% 0$ & $\% 2,6$ & $\% 5,3$ \\
\hline
\end{tabular}


Irati Sagardia Iturria, Agurtzane Martínez Gorrochategui

\begin{tabular}{|c|c|c|c|c|c|}
\hline ITEMAK & & GUZTIRA & 1. ZIKLOA & 2. ZIKLOA & 3. ZIKLOA \\
\hline 26. Norbaitek noizbait & BAI & $\% 65,8$ & $\% 13,2$ & $\% 34,3$ & $\% 18,5$ \\
\hline arazoak izan ditu & EZ & $\% 26,3$ & $\% 23,7$ & $\% 2,6$ & $\% 0$ \\
\hline $\begin{array}{l}\text { lkastetxean zehar } \\
\text { mugitzeko (hanka } \\
\text { puskatu duelako, } \\
\text { eskua...). }\end{array}$ & $\begin{array}{l}\text { EZ } \\
\text { DAKIT }\end{array}$ & $\% 7,9$ & $\% 0$ & $\% 0$ & $\% 7,9$ \\
\hline 27. Taldeak osatzeko & BAI & $\% 10,5$ & $\% 2,6$ & $\% 7,9$ & $\% 0$ \\
\hline irakasleak & $\mathrm{EZ}$ & $\% 86,6$ & $\% 31,6$ & $\% 29$ & $\% 26,4$ \\
\hline $\begin{array}{l}\text { alfabeto-ordenari } \\
\text { jarraitzen dio. }\end{array}$ & $\begin{array}{l}\text { EZ } \\
\text { DAKIT }\end{array}$ & $\% 2,6$ & $\% 2,6$ & $\% 0$ & $\% 0$ \\
\hline 28. Taldean nahi & BAI & $\% 34,2$ & $\% 2,6$ & $\% 26,3$ & $\% 5,3$ \\
\hline dugunarekin & EZ & $\%$ 42,1 & $\% 34,3$ & $\% 5,3$ & $\% 2,6$ \\
\hline $\begin{array}{l}\text { jartzen uzten } \\
\text { digu irakasleak. }\end{array}$ & $\begin{array}{l}\text { EZ } \\
\text { DAKIT }\end{array}$ & $\% \mathbf{2 3 , 7}$ & $\% 0$ & $\% 5,3$ & $\% 18,5$ \\
\hline 29. Taldeak aldatzen & BAI & $\% 97,4$ & $\% 36,9$ & $\% 34,3$ & $\% 26,4$ \\
\hline dira. & EZ & $\% 0$ & $\% 0$ & $\% 0$ & $\% 0$ \\
\hline & $\begin{array}{l}\text { EZ } \\
\text { DAKIT }\end{array}$ & $\% 2,6$ & $\% 0$ & $\% 2,6$ & $\% 0$ \\
\hline 30. Nire burua maite & BAI & $\% 94,7$ & $\% 34,3$ & $\% 34,3$ & $\% 26,4$ \\
\hline dut. & EZ & $\% 0$ & $\% 0$ & $\% 0$ & $\% 0$ \\
\hline & $\begin{array}{l}\text { EZ } \\
\text { DAKIT }\end{array}$ & $\% 5,3$ & $\% 2,6$ & $\% 2,6$ & $\% 0$ \\
\hline 31. Askotan beste & BAI & $\%$ 47,4 & $\% 21,1$ & $\% 2,6$ & $\% 23,7$ \\
\hline guztiek gauzak & $\mathrm{EZ}$ & $\% 15,8$ & $\% 7,9$ & $\% 7,9$ & $\% 0$ \\
\hline $\begin{array}{l}\text { nik baino hobeto } \\
\text { egiten dituztela } \\
\text { uste dut. }\end{array}$ & $\begin{array}{l}\text { EZ } \\
\text { DAKIT }\end{array}$ & $\% \mathbf{3 6 , 8}$ & $\% 7,9$ & $\% 26,3$ & $\% 2,6$ \\
\hline 32. Askotan gauzak & BAI & $\% 52,6$ & $\% 10,5$ & $\% 26,3$ & $\% 15,8$ \\
\hline gaizki egiten & $\mathrm{EZ}$ & $\% 34,2$ & $\% 23,7$ & $\% 0$ & $\% 10,6$ \\
\hline ditudala uste dut. & $\begin{array}{l}\text { EZ } \\
\text { DAKIT }\end{array}$ & $\% 13,2$ & $\% 2,6$ & $\% 10,6$ & $\% 0$ \\
\hline \multirow{3}{*}{$\begin{array}{l}\text { 33. Gaizki portatzen } \\
\text { garenean } \\
\text { batzuetan } \\
\text { irakasleak } \\
\text { ikasgelatik kanpo } \\
\text { bidaltzen gaitu. }\end{array}$} & BAI & $\% 63,2$ & $\% 2,6$ & $\% 34,3$ & $\% 26,4$ \\
\hline & $\mathrm{EZ}$ & $\% \mathbf{3 6 , 8}$ & $\% 34,3$ & $\% 2,6$ & $\% 0$ \\
\hline & $\begin{array}{l}\text { EZ } \\
\text { DAKIT }\end{array}$ & $\% 0$ & $\% 0$ & $\% 0$ & $\% 0$ \\
\hline
\end{tabular}


Ikasleen ahotsak: guztiontzako eskola eraikitzeko gakoa

\begin{tabular}{|c|c|c|c|c|c|}
\hline ITEMAK & & GUZTIRA & 1. ZIKLOA & 2. ZIKLOA & 3. ZIKLOA \\
\hline \multirow{3}{*}{$\begin{array}{l}\text { 34. Batzuetan } \\
\text { ikastolan } \\
\text { beldurra } \\
\text { pasatzen dut. }\end{array}$} & BAI & $\% 10,5$ & $\% 7,9$ & $\% 0$ & $\% 2,6$ \\
\hline & $\mathrm{EZ}$ & $\%$ 89,5 & $\% 29$ & $\% 36,9$ & $\% 23,7$ \\
\hline & $\begin{array}{l}\text { EZ } \\
\text { DAKIT }\end{array}$ & $\% 0$ & $\% 0$ & $\% 0$ & $\% 0$ \\
\hline \multirow{3}{*}{$\begin{array}{l}\text { 35. } \text { Beldurra } \\
\text { sentitzen } \\
\text { badut, badakit } \\
\text { norengana joan. }\end{array}$} & BAI & $\%$ 89,5 & $\% 36,9$ & $\% 34,3$ & $\% 18,4$ \\
\hline & $\mathrm{EZ}$ & $\% 7,9$ & $\% 0$ & $\% 2,6$ & $\% 5,2$ \\
\hline & $\begin{array}{l}\text { EZ } \\
\text { DAKIT }\end{array}$ & $\% 2,6$ & $\% 0$ & $\% 0$ & $\% 2,6$ \\
\hline \multirow{3}{*}{$\begin{array}{l}\text { 36. Iseka egiteko } \\
\text { goitizenak } \\
\text { erabiltzen dira. }\end{array}$} & BAI & $\% 36,8$ & $\% 5,3$ & $\% 7,9$ & $\% 23,7$ \\
\hline & $\mathrm{EZ}$ & $\% 52,6$ & $\% 28,9$ & $\% 21,1$ & $\% 2,6$ \\
\hline & $\begin{array}{l}\text { EZ } \\
\text { DAKIT }\end{array}$ & $\% 10,5$ & $\% 2,6$ & $\% 7,9$ & $\% 0$ \\
\hline \multirow{3}{*}{$\begin{array}{l}\text { 37. Niri iseka egiten } \\
\text { didate goitizenak } \\
\text { erabiliz. }\end{array}$} & BAI & $\% 26,3$ & $\% 15,8$ & $\% 10,6$ & $\% 0$ \\
\hline & $\mathrm{EZ}$ & $\% 71,1$ & $\% 21$ & $\% 23,7$ & $\% 26,4$ \\
\hline & $\begin{array}{l}\text { EZ } \\
\text { DAKIT }\end{array}$ & $\% 2,6$ & $\% 0$ & $\% 2,6$ & $\% 0$ \\
\hline
\end{tabular}

Politika aipatzean, ziurtatu nahi da inklusioa berritzapen-prozesuaren bihotzean egotea, politika guztiak zipriztinduz, hartara ikasle guztien ikasketa eta partaidetza hobetu daitezen (Booth eta Ainscow, 2002). Gainera, Eusko Jaurlaritzak (2012) dioen bezala, politika inklusiboen xedea ere bada, guztiontzako eskola izango den eskola egituratzeaz gain, aniztasunari kalitatez erantzuteko baliabideak antolatzea.

Hori kontuan hartuta, alderdi esanguratsu moduan, honako kategoria hauek azpimarratu nahi dira: espazioaren erabilera, instalazioak, baliabide materialak, denboraren kudeaketa eta diziplinazko zigorrak.

- Espazioaren erabilera. Ikasleek esandakoaren arabera, arazoak identifikatu dira patioaren erabileran. Gazteenek sentitzen dute helduenak patioaz jabetzen direla: «Nago haserre handiek kanpoa beti kentzen digutenean». Horregatik, hobetuko luketen alderdietako bat da: «Espazioa aprobetxatzea hobetuko nuke». Apainketa ere aipatu dute. Izan ere, bai ikasgela eta baita eskola ere orokorrean gutxi apainduta daudela adierazi dute lehen zikloko ikasleek: «Gela gehiago apaindu» eta «Eskola gehiago apaindu».

-Instalazioak. Ikasleek adierazi dutenaren arabera, hainbat alderdi daude hobetzekoak. Alde batetik, tamaina hobetu beharreko zerbait da haien ustez; bai patioan («patioa handiagoa izatea hobetuko nuke»), bai ikasgelan («klasea handitzea») eta baita eskolan orokorrean ere 
(«eskola handiagoa izatea»). Bestalde, adierazi dutenaren arabera, ez zaie gustatzen patioan dagoen zikinkeria: «kantxan dagoen zikinkeria ez dut gustuko eskolan»; eta, bestalde, 1.zikloan eskola orokorrean gutxi apaindua dagoela adierazi dute eta hori hobetu nahiko lukete: «gela gehiago apaindu» eta «eskola gehiago apaindu».

- Baliabide materialak. Ikasgelatik kanpo dauden baliabideei dagokienez, patioan oinarritu dira. Horrela, haiek aipatu dutenaren arabera, bertan dagoen materiala ez da nahikoa («Patioan material gutxi dago») edo orain dagoena hobetu beharko litzateke ( Futboleko porterietan sarea jartzea»). Ikasgelan dauden baliabideei dagokienez, ikasleek gustuko dituzte eskolan dauden ordenagailu eta pantaila digitalak («Ordenagailuak ez nituzke aldatuko eskolan»). Dena dela, beste batzuek berriak ekarriko lituzketela aipatu dute, eskolan hobetzeko alderdi bezala («Ordenagailu berriak jartzea»).

- Denboraren kudeaketa. Denboraren kudeaketari dagokionez, 11 ikasleren iritziz jolas-ordua laburregia da, eta luzeagoa izatea gustatuko litzaieke: «Eskolan aldatuko nuke patio ordua luzeagoa izatea». 5 minutu gehiago eskatzen dituzten ikasleetatik hasita («Jolastokian 5 minutu gehiago») bada 2 ordu gehiago izatea gustatuko litzaiokeenik ere («Patioan 2 ordu gehiago egotea»). Baina, horrez gain, denbora libre gehiago izatea gustatuko litzaiekela ere aipatu dute («Denbora libre gehiago izatea»).

- Diziplinazko esklusioak. Kategoria honetan identifikatu dira irakasleen iritziz ikasleak gaizki portatu direlako izan diren kaleratze edo zigorrak. \% 63,2k adierazi du gaizki portatzean irakasleak batzuetan ikasgelatik kanpo bidaltzen dituztela (ikus 3. taula). Horrekin lotuta, ikasleetako batek honela adierazi du hori gertatzen denean sentitzen duena: «Minduta, irakasle batek kalera botatzen didanean arrazoi gabe». 
Ikasleen ahotsak: guztiontzako eskola eraikitzeko gakoa

\section{Praktika}

4. taula

Galdetegiko praktikaren emaitzak

\begin{tabular}{|c|c|c|c|c|c|}
\hline ITEMAK & & GUZTIRA & 1. ZIKLOA & 2. ZIKLOA & 3. ZIKLOA \\
\hline \multirow{3}{*}{$\begin{array}{l}\text { Gai berri bat } \\
\text { hasten dugunean, } \\
\text { lehenengo hitz zailak } \\
\text { ikasten ditugu. }\end{array}$} & BAI & $\% 26,3$ & $\% 2,6$ & $\% 23,7$ & $\% 0$ \\
\hline & EZ & $\% 44,7$ & $\% 23,7$ & $\% 5,2$ & $\% 7,9$ \\
\hline & $\begin{array}{l}\text { EZ } \\
\text { DAKIT }\end{array}$ & $\% \mathbf{2 8 , 9}$ & $\% 0$ & $\% 5,3$ & $\% 21,1$ \\
\hline \multirow{3}{*}{$\begin{array}{l}\text { 39. Nahiz eta iritzi } \\
\text { ezberdina izan, } \\
\text { nire ideiak } \\
\text { partekatzen ditut. }\end{array}$} & BAI & $\% 68,4$ & $\% 10,5$ & $\% 34,2$ & $\% 23,7$ \\
\hline & EZ & $\% 13,2$ & $\% 10,6$ & $\% 0$ & $\% 2,6$ \\
\hline & $\begin{array}{l}\text { EZ } \\
\text { DAKIT }\end{array}$ & $\% 18,4$ & $\% 15,8$ & $\% 2,6$ & $\% 0$ \\
\hline \multirow{3}{*}{$\begin{array}{l}\text { 40. Guztien iritziak } \\
\text { errespetatzen } \\
\text { ditut. }\end{array}$} & BAI & $\% 92,1$ & $\% 34,2$ & $\% 31,6$ & $\% 26,4$ \\
\hline & EZ & $\% 0$ & $\% 0$ & $\% 0$ & $\% 0$ \\
\hline & $\begin{array}{l}\text { EZ } \\
\text { DAKIT }\end{array}$ & $\% 7,9$ & $\% 2,6$ & $\% 5,2$ & $\% 0$ \\
\hline \multirow{3}{*}{$\begin{array}{l}\text { 41. Besteen lekuan } \\
\text { askotan jartzen } \\
\text { naiz zer senti } \\
\text { dezaketen hobeto } \\
\text { ulertzeko. }\end{array}$} & BAI & $\% \mathbf{8 9 , 5}$ & $\% 34,2$ & $\% 29$ & $\% 26,4$ \\
\hline & $\mathrm{EZ}$ & $\% 2,6$ & $\% 2,6$ & $\% 0$ & $\% 0$ \\
\hline & $\begin{array}{l}\text { EZ } \\
\text { DAKIT }\end{array}$ & $\% 7,9$ & $\% 0$ & $\% 7,9$ & $\% 0$ \\
\hline \multirow{3}{*}{$\begin{array}{l}\text { 42. Irakasleak } \\
\text { kontutan hartzen } \\
\text { ditu nire interesak } \\
\text { gai berri bat } \\
\text { lantzen dugunean. }\end{array}$} & BAI & $\% 81,6$ & $\% 36,9$ & $\% 36,9$ & $\% 7,9$ \\
\hline & EZ & $\% 0$ & $\% 0$ & $\% 0$ & $\% 0$ \\
\hline & $\begin{array}{l}\text { EZ } \\
\text { DAKIT }\end{array}$ & $\% 18,4$ & $\% 0$ & $\% 0$ & $\% 18,5$ \\
\hline \multirow{3}{*}{$\begin{array}{l}\text { 43. Gainontzekoak } \\
\text { errespetatzen } \\
\text { ditut. }\end{array}$} & BAI & $\% 92,1$ & $\% 36,9$ & $\% 28,9$ & $\% 26,4$ \\
\hline & EZ & $\% 0$ & $\% 0$ & $\% 0$ & $\% 0$ \\
\hline & $\begin{array}{l}\text { EZ } \\
\text { DAKIT }\end{array}$ & $\% 7,9$ & $\% 0$ & $\% 7,9$ & $\% 0$ \\
\hline \multirow{3}{*}{$\begin{array}{l}\text { 44. Gainontzekoek } \\
\text { ni errespetatzen } \\
\text { naute. }\end{array}$} & BAI & $\% \mathbf{7 8 , 9}$ & $\% 34,2$ & $\% 18,5$ & $\% 26,4$ \\
\hline & $\mathrm{EZ}$ & $\% 0$ & $\% 0$ & $\% 0$ & $\% 0$ \\
\hline & $\begin{array}{l}\text { EZ } \\
\text { DAKIT }\end{array}$ & $\% 21,1$ & $\% 2,6$ & $\% 18,4$ & $\% 0$ \\
\hline \multirow{3}{*}{$\begin{array}{l}\text { 45. Besteak laguntzen } \\
\text { ditudanean nik ere } \\
\text { asko ikasten dut. }\end{array}$} & BAI & $\% 94,7$ & $\% 31,6$ & $\% 36,9$ & $\% 26,4$ \\
\hline & EZ & $\% 2,6$ & $\% 2,6$ & $\% 0$ & $\% 0$ \\
\hline & $\begin{array}{l}\text { EZ } \\
\text { DAKIT }\end{array}$ & $\% 2,6$ & $\% 2,6$ & $\% 0$ & $\% 0$ \\
\hline
\end{tabular}


Irati Sagardia Iturria, Agurtzane Martínez Gorrochategui

\begin{tabular}{|c|c|c|c|c|c|}
\hline ITEMAK & & GUZTIRA & 1. ZIKLOA & 2. ZIKLOA & 3. ZIKLOA \\
\hline \multirow{3}{*}{$\begin{array}{l}\text { 46. Batzuetan gu } \\
\text { gara zer ikasi } \\
\text { erabakitzen } \\
\text { dugunak. }\end{array}$} & BAI & $\% 92,1$ & $\% 34,2$ & $\% 31,6$ & $\% 26,4$ \\
\hline & $\mathrm{EZ}$ & $\% 2,6$ & $\% 2,6$ & $\% 0$ & $\% 0$ \\
\hline & $\begin{array}{l}\text { EZ } \\
\text { DAKIT }\end{array}$ & $\% 5,3$ & $\% 0$ & $\% 5,2$ & $\% 0$ \\
\hline \multirow{3}{*}{$\begin{array}{l}\text { 47. Klase gehienak } \\
\text { gustuko ditut. }\end{array}$} & BAI & $\% 86,8$ & $\% 36,9$ & $\% 34,3$ & $\% 15,8$ \\
\hline & EZ & $\% 10,5$ & $\% 0$ & $\% 2,6$ & $\% 7,9$ \\
\hline & $\begin{array}{l}\text { EZ } \\
\text { DAKIT }\end{array}$ & $\% 2,6$ & $\% 0$ & $\% 0$ & $\% 2,6$ \\
\hline \multirow{3}{*}{$\begin{array}{l}\text { 48. Irakasleari ez zaio } \\
\text { inporta saiatzen } \\
\text { naizen bitartean } \\
\text { gauzak gaizki } \\
\text { egiten baditut. }\end{array}$} & BAI & $\% 86,8$ & $\% 34,2$ & $\% 31,6$ & $\% 21$ \\
\hline & $\mathrm{EZ}$ & $\% 5,3$ & $\% 2,6$ & $\% 0$ & $\% 2,6$ \\
\hline & $\begin{array}{l}\text { EZ } \\
\text { DAKIT }\end{array}$ & $\% 7,9$ & $\% 0$ & $\% 5,2$ & $\% 2,6$ \\
\hline \multirow{3}{*}{$\begin{array}{l}\text { 49. Ikasgelan beti } \\
\text { dakit zer egin } \\
\text { behar dudan. }\end{array}$} & BAI & $\% 55,3$ & $\% 26,3$ & $\% 21,1$ & $\% 7,9$ \\
\hline & EZ & $\% 26,3$ & $\% 10,6$ & $\% 5,3$ & $\% 10,5$ \\
\hline & $\begin{array}{l}\text { EZ } \\
\text { DAKIT }\end{array}$ & $\% 18,4$ & $\% 0$ & $\% 10,6$ & $\% 7,9$ \\
\hline \multirow{3}{*}{$\begin{array}{l}\text { 50. Etxerako lanak } \\
\text { bidaltzen } \\
\text { dizkigutenean } \\
\text { ulertzen dut egin } \\
\text { beharrekoa. }\end{array}$} & BAI & $\% 84,2$ & $\% 31,6$ & $\% 29$ & $\% 23,7$ \\
\hline & $\mathrm{EZ}$ & $\% 7,9$ & $\% 2,6$ & $\% 2,6$ & $\% 2,6$ \\
\hline & $\begin{array}{l}\text { EZ } \\
\text { DAKIT }\end{array}$ & $\% 7,9$ & $\% 2,6$ & $\% 5,2$ & $\% 0$ \\
\hline
\end{tabular}

- Ikasten laguntzen duten alderdiak. Inongo zalantzarik gabe, arrazoi askoren ondorioz, talde-lana da ikasleek gustuko duten eta haientzako garrantzitsua den alderdietako bat, 46 ebidentziarekin. Lehenik eta behin, adierazi dutenaren arabera, gustuko dute eta garrantzitsua da taldean lan egitea, elkarri laguntzen diotelako: «Gehiago ikasten delako; igual bakarrik bazaude eta galdera badaukazu ezin diozu inorri galdetu eta horrela taldekoak laguntzen dizute». Elkarri laguntzeaz gain, adierazi dute horrela lagunekin ikasteko aukera ere badutela («Nahiago det taldean, zeba, gehiago gustatzen zait, lagunekin nagoelako»). Bestalde, adierazi dute prozesua errazagoa egiten zaiela («Niri gustatzen zait taldea, ze horrela lanak eta egitea gutxiago kostatzen zait»), eta baita elkarri irakasten diotela ere ( «Ikasten dezu besteei laguntzen, denen iritzia errespetatzen, eta besteek ikasten dute zuri laguntzen ere»). Zehazki \% 94,7k adierazi $\mathrm{du}$ besteak laguntzen dituztenean, beraiek ere asko ikasten dutela. Aipatzekoa da, bigarren eta hirugarren zikloan alderdi hori ikasle 
guztiek garbi daukatela. Lehenengo zikloan aldiz \% 2,6k ezetz adierazi du eta beste $\% 2,6 \mathrm{k}$ ez dakiela (ikus 4 . taula). Talde-lanari dagokionez, ikasle batzuek adierazi dute, taldean lan egitea gustatzen zaien arren, taldearen arabera nahiago dutela bakarka edo taldean lan egin. Izan ere, batzuek, taldean egon arren, ez dute talde-lanik egiten («Neri, segun ze taldetan, ondo balin bagaude bai, baino badaude batzuk lanean eta beste batzuk hitz egiten ez»). Bestalde, ikasleek garrantzitsutzat jo dute ikastea dibertigarria izatea. Adierazi duten bezala, eskolara gusturago etortzeko arrazoia da («Ikastea dibertigarriago egiten badezu, eskolara pozikago etortzen zera»); baina, horrez gain, funtsezko baldintza da ikaste-prozesuan zehar ( «Ikasleak joaten dira eskolara como... puajjrrr.... Ez daukate gogoa eta ez dute ikasten asko eta ikasteko gogoa eduki behar da»).

- Ikastea oztopatzen duten alderdiak. Ikasleek esandakotik, ikasleen ikaste-prozesua oztopatzen duten edo gustuko ez dituzten bi alderdi nagusi identifikatu dira: irakaslearen jarrera negatiboa eta ikasleen arteko elkarlan falta. Lehenik eta behin, irakaslearen jarrera negatiboa identifikatu da. Horren barruan, ikasleei ez zaie gustatzen irakasleek protagonismo nagusia hartzea. Hau da, eskolan ez zaie gustatzen irakasleak gauzak denbora luzez azaltzea («Irakasle_1-en txapak dira eskolan gutxien gustatzen zaidana»); izan ere, aspertu egiten direla adierazi dute («Baino gero enroilatzen da pila bat. Istoriak kontatzen dizkigu. Aburritzen gera pila bat»). Gainera, irakasle izango balira zer egingo luketen galdetzean, hiru ikaslek adierazi dute ez luketela hainbeste hitz egingo ( Irakaslea izango banintz txapa gutxiago emango nituzke»). Baina, horrez gain, ikaste-irakaste prozesua jolasetara bideratuko luketela ere adierazi dute ( «Jolasak egingo nituzke txapak eman ordez»). Umoreari dagokionez, ikasleek adierazi dute ez zaiela gustatzen irakaslea umore txarrean egotea («Irakaslea umore txarrean egotea ez zait gustatzen eskolan»). Adierazi dutenaren arabera, eskolan ikasleak batzuetan haserretzen dira ez dituztelako irakasle batzuen haserreak ulertzen, eta, ondorioz, irakasleek irakasten duten materian gustura ez egotea baldintzatzen du horrek («Haserre, matematikak egitean. Ze haserretzen da batzutan arrazoi gabe ta...»). Bestalde, lehenago adierazi bezala, talde-lana da ikasleentzat garrantzitsua den alderdietako bat. Horregatik, adierazi dute haientzat ikaste-prozesuan oztopoa dela talde-lanean ari diren bitartean ikasleen artean elkarlan falta sumatzea. Izan ere, bidegabekeria iruditzen zaie batzuk taldean lanean ari diren bitartean beste batzuk beste gauza batzuk egiten aritzea ( $\ll E z$ da bidezkoa, taldean zaudenean batzuk lanean egotea eta beste batzuk ez»). Horrek baldintzatzen die taldean gustura edo ez gustura lan egitea («Neri segun ze taldetan, ondo baldin bagaude bai, baino badaude batzuk lanean eta beste batzuk hitz egiten ez»). 
- Eskolan gustuko dutena. 42 ebidentziarekin, garbi geratu da eskolan jolastea dela ikasleei gehien gustatzen zaiena. Forma ezberdinetako jolasak gustatzen zaizkie: ordenagailuetan aritzea («Ordenagailuetan jolasten pasatzen dut ondo klasean»), patioan ibiltzea («Patio ordua iristen denean») edo jokoak egitea («Jokuak egiten ditugunean pasatzen dut ondo klasean»). Hala ere, esanguratsua da aipatzea, ikasleei zer hobetuko luketen galdetzean, jokoen bidez irakatsiko luketela proposatu dutela («Irakaslea izango banintz, egiten gauzak jolasteko, gauzak irakatsiko nituzke»). Artearen azpikategorian barne hartu dira artearekin erlazioa daukaten jarduerak. Horrela, ikusi da ikasleek gustuko dituztela margotzearekin eta pelikula ikustearekin erlazionaturiko jarduerak ( Pelikulak ikusten pasatzen dut ondo klasean»). Irakasle izango balira zer egingo luketen galdetzean, honako erantzun hauek eman dituzte: «Irakaslea izango banintz, marrazten irakatsiko nuke» edo «Irakasteko pelikulak jarriko nituzke». Amaitzeko, IKTei dagokienez, ikusi da ikasleei gustatzen zaiela ikasgelan dauzkaten baliabide teknologikoak erabiltzea («Ordenagailuetan pasatzen dut ondo klasean»). Baina, horrez gain, ordenagailuak jolastearekin ere erlazionatzen dituzte, eta hori gustuko dute ikaste-irakaste prozesuari begira ( Irakaslea izango banintz, beti ordenagailuetan jolastuz ikasiko genuke»).

- Eskolan gustuko ez dutena. Jarduera tradizionalekin, ikaste-irakaste prozesuetan ohikoak diren alderdiak azpimarratu nahi dira. Besteak beste, fitxak egitea, idaztea, irakurtzea eta testuliburuak. Horrela, jarduera tradizionalak biltzen dituzten ebidentziak 26 izan dira. Gustuko ez duten jarduera tradizionaletan gehien aipatu direnak izan dira fitxak egitea eta kaligrafia egitea. Bestalde, ikasleei eskolan zer gustatzen ez zaien galdetzean, asko izan dira materiei erreferentzia egin dietenak. Zehazki 41 ebidentzia bildu dira, eta gutxien gustatzen zaizkien materiak ingelesa eta matematika dira. Hala ere, \% 86,8k adierazi du klase gehienak gustuko dituela. Zehazki, 1. zikloko \% 100ak adierazi du baietz. 2. zikloan \% 2,6k adierazi du ezetz eta 3. zikloan, ezetz adierazitakoak \% 7,9 izan da.

\section{Besteak}

Amaitzeko, Index for Inclusion gidan biltzen ez den kategoriatik at, espero ez zen kategoria bat identifikatu da. Eskolako zerbitzuarekin erlazionatutakoa izan da hori; eskolan, ikasle gehienek argi eta garbi adierazi dute eskolako jangelan zerbitzatzen duten janaria dela gutxien gustatzen zaiena, eta, ondorioz, hobetzeko alderdi bezala proposatu dute («Jangelako janaria hobea izatea hobetuko nuke eskolan»). 


\section{EZTABAIDA ETA ONDORIOAK}

Ikerketa honetan ikusi den bezala, ikasleek gustuko dute komunitateko partaide direla sentitzea, eta, alderantziz, ez zaie gustatzen komunitate horretako partaide ez sentitzea. Azken hori esklusio mota ezberdinekin erlazionatu da; zehazki, bazterketekin, irain eta isekekin, erasoekin eta errespetu faltekin. Alderdi horiek ikasleentzat negatibo edo mingarriak diren arren, ohikoak izaten dira orokorrean (Mahbub, 2008).

Bestalde, ikasleek desegokitzat jotzen dute erabaki eta arau batzuk zentzugabeak edo bidegabeak izatea. Horregatik, eskolako arau eta erabakietan parte-hartze handiagoa izatea gustatuko litzaieke. Boothek eta Ainscowek (2011) dioten bezala, hezkuntzan ez da askotan parte-hartzerik bilatzen, eta garrantzitsua da, inplikatzeaz gain onartuak direla sentiarazten baitie ikasleei. Azken finean, gauzatzen diren akzioen jatorria zein den jakitean, aktiboago parte hartzen laguntzen du.

Ikastetxea txikia izanda, instalazioak ere txikiak dira, eta hori ikasleentzat negatiboa dela ikusi da, batez ere patioan, horrek gatazkak eragiten baititu ziklo ezberdineko ikasleen artean. Horren inguruan, ikusi da gatazkarik gehienak adinaren eta sexuaren araberakoak izaten direla (Filella et al., 2016); hala ere, ikastetxe honetan sexuen arteko gatazkarik identifikatu ez den arren, bat dator adinaren arteko gatazkekin. Horrekin lotuta, adin ezberdineko ikasleen artean ezberdintasunak izaten direla identifikatu da. Baita irakasleek adin ezberdinekoekiko eta ikasle batzuekiko duten jarreran ere. Horrela, ondorioztatu da komunitate-esentzia, zikloka baden arren, ziklo ezberdinen artean ez dela nahikoa agertzen. Cabajalek (2013) aipatzen duen bezala, eskola demokratiko baterako bidean, beharrezkoa da ikasleei beren gatazkak konpontzen uztea. Azken finean, eskolak izaten dira haurren lehenengo espazioak, non kontaktua duten, beren egunerokotasunean, gizakien aniztasunarekin. Horri esker, espazio pribilegiatu bihurtzen dira gatazka horiek kudeatzen ikasteko; izan ere, harremanak dauden eremu guztietan izango dira gatazkak. Horrela, irakasleek zuzenean gaztetxoenei babesa eskaini beharrean, aukera egokia litzateke, ondoren helduenek babes falta sentitzen dutelako, gatazkak modu baketsuan eta asertziozko komunikazioaren bidez ebazten irakastea (Cabajalen, 2013).

Ikastea oztopatzen duten alderdien artean, irakaslearen jarrera negatiboa adierazi dute. Zehazki, protagonismo nagusia hartzen duenean eta umore txarrean dagoenean. Ezin da ahaztu, aniztasunari erantzuteko, beharrezkoa dela ikasle guztien parte-hartzea eta ikaste-prozesuak erraztuko dituen metodologia (Duran eta Giné, 2017). Kasu honetan, proiektuka lan egiten duten arren, ikusi da ikasleak aspertu egiten direla parte hartzen ari ez direnean edo protagonista nagusi ez direnean, eta horrek kalitatezko ikaste-prozesua oztopatzen duela. Bestalde, irakaslearen umorea ere funtsezko moduan hartu dute. Gaur egun, korronte pedagogiko dezentek defendatzen dute umore positiboa, ondo pasaraztea eta barrea; izan ere, baliagarriak dira irakaslearen rolean. Alde ba- 
tetik, Jauregik eta Fernandezek (2009) adierazi bezala, horren bitartez irakasleekin harreman hobea eraikitzen da, estresa eta antsietatea gutxitzen dira, eta gatazkak kudeatzen dira. Baina, horrez gain, aipatu dute jarrera horren bitartez ikasleak parte hartzera eta ikastera motibatzen direla, baita komunikazioa eraginkorragoa dela ere, eta horrela ikasleen atentzioa, sormena eta oroimena garatzen direla.

Talde-lanari dagokionez, aztertu da ikasle guztiek garrantzia ematen dioten alderdia dela eta ikasten laguntzen diela. Hala ere, esan beharra dago, lehen zikloan baino garrantzi handiagoa ematen diotela bigarren eta hirugarren zikloetan. Mahbubek (2008) bere ikerketan aztertu bezala, ikasleek badakite zein garrantzitsua den ikaskideei laguntzea, eta, oro har, nahiago dute taldean lan egin bakarka baino.

Bestalde, hobekuntza moduan, klaseak dibertigarriagoak izatea proposatu dute. Horretarako, IKTak eta jolasak proposatzen dituzte. Gaur egun, teknologia funtsezkoa bihurtu da gure egunerokotasunean, eta IKTak tresna bikaina dira ikasleen aniztasunari erantzuteko ere (Lopez, 2016). Alde batetik, ikasle bakoitzaren erritmoa errespetatzen, ikaste-prozesuak esanguratsu bihurtzen eta ikasleen interesak eta motibazioak asetzen laguntzen dute. Bestalde, aldatzen ari da irakaslearen rola. Hau da, edukia transmititzeak ez dauka inolako zentzurik, eta, horren ordez, irakasleak gidari-lana gauzatu behar du ikasleen motibazioa mantenduz, besteak beste (Lopez, 2016). Azken finean, balio inklusiboak pertsonen garapen integralarekin lotzen dira, horrela emozioak eta sentimenduak barne hartuz. Hezkuntza alai batek jokoaren, dibertsioaren eta umore partekatuaren bitartez bideratzen ditu ikaste-prozesuak, modu egokiena baita interes, ezagutza eta gaitasunak mantentzeko (Booth eta Ainscow, 2011).

\section{ERREFERENTZIAK}

Ainscow, M., Booth, T. eta Dyson, A. (1999). «Inclusion and exclusion in schools: listening to some hidden voices». In: Ballard, K. (1999) Inclusive Education: International Voices on Disability and Justice. Londres: Falmer Press.

Ainscow, M., Booth, T., Dyson, A., Farrell, P., Frankham, J., Gallannaugh, F., Howes, A., eta Smith. R. (2006). Improving schools, developing inclusion. Londres: Routledge.

Alvarez, J. D., Grau, S., eta Tortosa, M. T. (2014). Estrategias organizativas para una escuela inclusiva. International Journal of Developmental and Educational Psychology, 7(1), 53-62. DOI: https://doi.org/10.17060/ijodaep.2014. n1.v7.776

Arnáiz, P. (2003). Educación inclusiva. Una escuela para todos. Málaga: Aljibe.

Blanco, R. (2008). Marco conceptual sobre educación inclusiva. 48. ${ }^{a}$ Reunión de la Conferencia Internacional de Educación. La educación inclusiva: el camino hacia el futuro. Documento Final. 
Booth, T. eta Ainscow, M. (2002). Index For Inclusion. Bristol: CSIE. Hemendik jasoa: https://www.eenet.org.uk/resources/docs/Index English.pdf (2018ko azaroaren 22an kontsultatua).

Booth, T. eta Ainscow, M. (2011). Guía para la Educación Inclusiva. Desarrollando el aprendizaje y la participación en los centros escolares. Index for inclusion gidaren 3. argitalpen berrikusia. Bristol: CSIE.

Booth, T., Ainscow, M., Black-Hawkins, K., Vaughan, M., eta Shaw, I. (2000). Index for Inclusion: Developing learning and participation in schools. Bristol, Centre for Studies on Inclusive Education.

Canney, C. eta Byrne, A (2006). Evaluating circle time as a support to social skills development: Reflection on a journey in school based research. British journal of special education, 33(1), 19-24.

Carbajal, P. (2013). Convivencia democrática en las escuelas. Apuntes para una reconceptualización. Revista Iberoamericana de Evaluación Educativa, 6(2), 13-35. Hemendik jasoa: https://revistas.uam.es/index.php/riee/article/ view/3403 (2018ko azaroaren 22an kontsultatua).

Cheminais, R. (2008). Engaging Pupil Voice to Ensure that Every Child Matters. A practical Guide. Londres: Routledge.

Collins, B. (2011). Empowering children through circle time: an illumination of practice $(P h D)$. National University of Ireland Maynooth. Hemendik jasoa: http://eprints.maynoothuniversity.ie/3728/ (2018ko azaroaren 22an kontsultatua).

Corbett, J. (2001). Teaching approaches which support inclusive education: a connective pedagogy. British Journal of Special Education, 28(2), 55-59.

Creswell, J. W. (2007). Qualitative inquiry and research design: choosingamong five approaches. Thousand Oaks, CA: Sage.

Davies, L. (2000). Researching democratic understanding in primary school. Research in Education, 61, 39-48. DOI: https://doi.org/10.7227/RIE.61.5

Duran, D. eta Giné, C. (2017). La formación del profesorado para la educación inclusiva: un proceso de desarrollo profesional y de mejora de os centros para atender la diversidad. La formación del profesorado para la educación inclusiva, 153-170. Hemendik jasoa: http://repositoriocdpd. net:8080/bitstream/handle/123456789/1913/Art_DuranGisbertD_Formaciondelprofesorado.pdf? sequence=1 (2018ko azaroaren 22an kontsultatua).

Dyson, A., eta Millward, A. (2000). Schools and special needs: Issues of innovation and inclusion. Londres: Paul Chapman.

Echeita, G. (2008) Inclusión y exclusión educativa. «Voz y quebranto». Revista Electrónica Iberoamericana sobre Calidad, Eficacia y Cambio en Educación, 6(2), 9-18. Hemendik jasoa: http://www.redalyc.org/pdf/551/55127024005. pdf (2018ko azaroaren 22an kontsultatua).

Echeita, G. eta Sandoval, M. (2002). Educación inclusiva o educación sin exclusiones. Revista de Educación, 327, 31-48.

Eusko Jaurlaritza (2012). Eskola Inklusiboaren esparruan Aniztasunari erantzuteko Plan Estrategikoa 2012-2016. Hemendik jasoa: http://www.hezkuntza. ejgv.euskadi.eus/r43-2459/eu/contenidos/informacion/dig_publicaciones_innovacion/eu_escu_inc/adjuntos/16_inklusibitatea_100/100011e_Pub_EJ_ Plan_diversidad_e.pdf (2018ko azaroaren 22an kontsultatua). 
Filella, G., Ros-Morente, A, Rueda, P., Solano, A. eta Minguella, E. (2016). Analisis de conflictos entre iguales en las escuelas de educación primaria. Revista de Educación Social, 23, 301-314. Hemendik jasoa: http://www.ub.edu/grop/ wp-content/uploads/2014/03/RES.pdf (2018ko azaroaren 22an kontsultatua).

Hernández Sampieri, R., Fernández Corrado, C., eta Baptista Lucio, P. (2014). Metodología de la Investigación (6. edizioa). McGraw-Hill Interamericana. Hemendik jasoa: http://observatorio.epacartagena.gov.co/wp-content/ uploads/2017/08/metodologia-de-la-investigacion-sexta-edicion.compressed. pdf (2019ko otsailaren 10ean kontsultatua).

Hezkuntza, Unibertsitate eta Ikerketa Saila (d.g). Heziberri 2020, Hezkuntza Eredu Pedagogikoaren Markoa. Hemendik jasoa: http://www.euskadi.eus/contenidos/informacion/heziberri_2020/eu_heziberr/adjuntos/Heziberri_2020_e.pdf (2018ko azaroaren 22an kontsultatua).

Housego, E., eta Burns, C. (1994). Are you sitting too comfortably? A critical look at ,circle time“ in primary classrooms. English in Education, 28(2), 23-29.

Jauregui, E. eta Fernandez, J. D. (2009). Risa y aprendizaje: el papel de humor en la labor docente. Revista Interuniversitaria de Formacion del Profesorado, 23(3), 203-215. Hemendik jasoa: http://www.redalyc.org/articulo. oa $? \mathrm{id}=27419066011$ (2018ko azaroaren 22an kontsultatua).

Latess, J. D. (2008). Focus-group research for school improvement: What arethey thinking?. New York, NY: Rowman \& Littlefield.

Lindley, E., Brinkhuis, R. eta Verhaar, L. (2011). Too young to have a voice? Exploring how to include young children in a school council. Miles, S. Eta Ainscow, M. (2011). Responding to diversity in schools. An inquiry-based approach. Londres: Routledge.

Lopez, A. L. (2007). Using Reflective Processes to Promote Attention to Diversity in Schools: A study of Practice in Chile. Revista Enfoques Educacionales, 10(1), 163-197. Hemendik jasoa: https://revistas.uchile.cl/index.php/REE/article/view/47069/49064 (2018ko azaroaren 22an kontsultatua).

Lopez, C. (2016). Enseñar con TIC. Nuevas y renovadas metodologías para la Enseñanza Superior. CINEP. Hemendik jasoa: https://issuu.com/helpdeskmoodlecinep/docs/ensin_ar_con_tic (2018ko azaroaren 22an kontsultatua).

Lown, J. (2002). Circle time: the perceptions of teachers and pupils. Educational Psychology in Practice, 18(2), 93-102.

Mahbub, T. (2008). Inclusive education at a BRAC school- perspectives from the children. British Journal of Special Education, 35(1), 33-41.

Mahbub, T. (2016). Rethinking inclusive education in Bangladesh through an examination of children's voices and Rabindranath Tagore's pedagogical philosophy. (PhD Thesis).

Mayall, B (2000). Conversations with children: working with generational issues. P. Christensen, \& A. James, Advocating for children: International Perspectives on Children's Rights (120-135). Londres: Falmer.

McDowell, L. (2001). 'It's that Linda again': Ethical, practical and political issues involved in longitudinal research with young men. Ethics, Place and Environment, 4(2), 87-100.

McNamara, S. eta Moreton, G. (1995). Changing Behaviour: Teaching Children with Emotional and Behavioural Difficulties in Primary and Secundary Classroom. Londres: David Fulton. 
Messiou, K. (2003) Conversations with children: A pathway towards understanding marginalisation and inclusive education. $\mathrm{PhD}$ thesis. University of Manchester. Hemendik jasoa: http://ethos.bl.uk/OrderDetails.do?uin=uk. bl.ethos.515068 (2018ko azaroaren 22an kontsultatua).

Messiou, K. (2012). Confronting Marginalisation: A framework for promoting inclusion. Londres: Routledge.

Susinos, T. eta Ceballos, N. (2012). Voz del alumnado y presencia participativa en la vida escolar. Apuntes de una cartografía de la voz del alumnado en la mejora educativa. Revista de Educación, 359, 24-44.

Tertoolen, A.; van Oers, B.; Geldens, J. eta Popeijus, H. (2016). Exploring the Content of Young Children's Multidimensional Voice Related to School Contexts. RRJES, 2(1), 6-17.

UNESCO (2008). La educación inclusiva: El camino hacia el futuro. Documento de referencia. Geneva.

UNESCO (2010). Ept Informe de seguimiento 2010. Llegar a los marginados. Paris.

UNESCO. (2015). Education 2030: Incheon Declaration and Framework for Action. Towards inclusive and equitable quality education and lifelong learning for all. Paris.

UNESCO (2016). La educación al servicio de los pueblos y el planeta: creación de futuros sostenibles para todos. Paris.

United Nations (1989). UN convention on the rights of the child. New York.

Valentine, G. (1999). Being seen and heard? The ethical complexities of working with children and young people at home and at school. Ethics, place and environment, 2(2), 141-155. 